\title{
Effects of PPAR and RXR ligands in semaphorin 6B gene expression of human MCF-7 breast cancer cells
}

\author{
HOSSAM MURAD $^{1}$, PHILIPPE COLLET ${ }^{1}$, CECILE HUIN-SCHOHN ${ }^{1}$, NEHMANN AL-MAKDISSY ${ }^{1}$, \\ GERALDINE KERJAN ${ }^{2}$, ALAIN CHEDOTAL ${ }^{2}$, MIREILLE DONNER ${ }^{1}$, MARIE DOMINIQUE DEVIGNES ${ }^{3}$, \\ PHILIPPE BECUWE ${ }^{1}$, HERVE SCHOHN $^{1}$, LIONEL DOMENJOUD $^{1}$ and MICHEL DAUÇA ${ }^{1}$ \\ ${ }^{1}$ IFR 111/EA 3446 'Peroxisome Proliferators', Faculty of Sciences, BP 239, University Henri Poincaré-Nancy I, \\ 54506 Vandoeuvre-les-Nancy; ${ }^{2}$ UMR 7102 ‘Neurobiologie des Processus adaptatifs', Université P. et M. Curie, \\ 75005 Paris; ${ }^{3}$ LORIA, CNRS-UMR 7503 Laboratoire Lorraine de Recherche en Informatique \\ et Ses Applications, 54506 Vandoeuvre-les-Nancy, France
}

Received May 30, 2005; Accepted July 7, 2005

\begin{abstract}
This study tests the hypothesis that the activators of peroxisome proliferator-activated receptors (PPARs) and 9-cis-retinoic acid receptor (RXR) regulate human semaphorin 6B (Sema6B) gene expression. The human MCF-7 breast adenocarcinoma cell line was chosen because it expresses Sema6B at a high level. The Sema6B mRNA level was analyzed by RT-PCR and the semaphorin $6 \mathrm{~B}$ protein content was determined using a polyclonal antibody that we have produced and characterized. Treatments with fenofibrate (a PPAR $\alpha$ activator) and troglitazone (a PPAR $\gamma$ ligand) strongly decreased the Sema6B mRNA. The drop in Sema6B mRNA level and in protein content was more important when the treatment combined the action of fenofibrate or troglitazone and 9-cis-retinoic acid.On the other hand, no significant change was observed in the Sema6B mRNA and protein levels when the cells were exposed to the combined action of GW610742 (a PPARß activator) and 9-cis-retinoic acid. These data suggest that PPAR $\alpha /$ RXR and PPAR $\gamma / \mathrm{RXR}$ heterodimers are involved in the regulation of Sema6B gene expression and open new perspectives concerning the participation of these nuclear receptors in cell recognition and migration.
\end{abstract}

\section{Introduction}

Semaphorins are members of a large, highly conserved family of signalling molecules that were identified initially for their role in axon guidance and neural network formation $(1,2)$ and later recognized to control a broad range of functions, from

Correspondence to: Dr Hossam Murad, EA 3446 'Peroxisome Proliferators', Faculty of Sciences, BP 239, 54506 Vandoeuvre-lesNancy, France

E-mail: Hossam.Murad@scbiol.uhp-nancy.fr

Key words: semaphorins, semaphorin 6B, peroxisome proliferator, peroxisome proliferator-activated receptor, 9-cis-retinoic acid receptor, MCF-7 cells cell migration and immune response to angiogenesis and cancer (3). So far, more than 20 semaphorins have been identified and divided into 8 classes. The first two classes are found in invertebrates, classes 3-7 are vertebrate semaphorins, while class 8 contains viral semaphorins (4). The semaphorins are secreted membrane-anchored or transmembrane proteins characterized by a conserved semaphorin domain which is approximately 500 amino acids long. In contrast to other semaphorins, class-6 semaphorins do not contain additional structural motifs such as immunoglobulin like domains (classes 2-4 and 7), thrombospondin repeats (class 5) and basic domains (class 3) (5). However their cytoplasmic domains contain several proline-rich potential $\mathrm{SH} 3$ domain binding sites and interact with several signalling proteins such as Abl (6) and enabled/vasodilator-stimulated phosphoprotein-like protein $(6,7)$. Sema6B was also shown to bind the SH3 domain of the protooncogene, c-src (8).

It has been recently shown that the human Sema6B gene exhibits a responsive element for PPARs (9). The latter are members of the superfamily of nuclear hormone receptors and present three isotypes: PPAR $\alpha$, PPARß (also called PPAR $\delta$, NUC-1, or FAAR), and PPAR $\gamma$ (10). PPARs are activated by their respective ligands, form heterodimers with the retinoid $\mathrm{X}$ receptor and bind to responsive elements of target genes (11). It has been reported that Sema6B mRNA level is decreased in human T98G glioblastoma cells by PPAR $\alpha$ agonists (9). However, no indication concerning the effect of these activators at the protein level was given and the impact of the other PPAR isotypes was not investigated. The aim of the present study was precisely to complete these previous investigations. The MCF-7 breast adenocarcinoma cell line was chosen because it is a non-neural cell line allowing extension of our previous data; it expresses the Sema6B gene at a high level and exhibits in vitro invasive capacity. Our results demonstrate that the combined treatments of MCF-7 cells with fenofibrate (a potent PPAR $\alpha$ activator) or troglitazone (a PPAR $\gamma$ agonist) and 9-cis-retinoic acid (the specific ligand of RXR) strongly decrease Sema6B gene expression at the transcriptional and translational levels. On the other hand, GW610742, an activator of PPARß does not induce any significant change. The finding 
that PPAR $\alpha$ or PPAR $\gamma$ and RXR activators down-regulate Sema6B gene, opens new perspectives for these nuclear receptors concerning their sphere of activity.

\section{Materials and methods}

Chemicals. Fenofibrate and 9-cis-retinoic acid were from Sigma Chemical Co. (St. Louis, MO, USA). Troglitazone was from Calbiochem-Novabiochem Corporation (San Diego, CA). GW610742 was a generous gift from GlaxoSmithKline (Stevenage, UK). Eagle minimum essential medium and Iscove's modified Dulbecco's medium, fetal bovine serum (FBS), primers for RT-PCR, dNTP, reverse transcriptase, Taq polymerase and RNase were purchased from Invitrogen (Cergy Pontoise, France). TNT-coupled wheat germ extract system for in vitro translation was provided by Promega Corp. (Madison, WI, USA). The cocktail of protease inhibitors (Complete) and the BM chemiluminescence kit were from Roche (Mannheim, Germany). The polyclonal antibody directed against glyceraldehyde-3-phosphate dehydrogenase (GAPDH) was from Chemicon International (Temecula, CA, USA) and goat anti-rabbit biotinylated IgG and streptavidin/ peroxidase mix were from Dako S.A. (Trappes, France). The Vector NovaRed substrate kit for peroxidase was obtained from Interchim (Montluçon, France). All other products were of reagent grade.

Cell culture and treatments. T98-G (12) and U-87 MG (13) glioblastoma cells, SH-SY5Y (14) neuroblastoma cells, HepG2 hepatoblastoma cells (15) and THLE-5B liver cells (16), HT-29 (17) and HCT 116 (18) colorectal carcinoma cells, MRC-5 (19) and A-549 (20) lung cells, L-293 kidney cells (21), and MCF-7 breast adenocarcinoma cells (22) were grown in Eagle's minimum essential medium with $2 \mathrm{mM}$ L-glutamine and Earle's BSS containing $1.5 \mathrm{~g} / 1$ sodium bicarbonate and $0.1 \mathrm{mM}$ non-essential amino acids and $1.0 \mathrm{mM}$ sodium pyruvate. The medium was supplemented with $10 \%(\mathrm{v} / \mathrm{v})$ heat-inactivated FBS $\left(56^{\circ} \mathrm{C}\right.$ for $\left.30 \mathrm{~min}\right)$. A final $20 \%(\mathrm{v} / \mathrm{v})$ FBS concentration was applied for the culture of Caco-2 colorectal adeno-carcinoma cells (17). Chronic myelogenous leukemic K-562 cells (23) were grown in Iscove's modified Dulbecco's medium with $4 \mathrm{mM}$ L-glutamine adjusted to contain $1.5 \mathrm{~g} / 1$ sodium bicarbonate and $10 \%$ fetal bovine serum. Cells were cultured at $37^{\circ} \mathrm{C}$ in a water-saturated atmosphere with $5 \% \mathrm{CO}_{2} / 95 \%$ air. The culture medium was renewed each day. Cells were treated either with vehicle $(0.1 \%$ DMSO) alone or with $500 \mu \mathrm{M}$ fenofibrate, or with

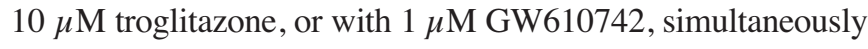
or not with $1 \mu \mathrm{M}$ 9-cis-retinoic acid.

Semi-quantitative reverse transcription polymerase chain reaction $(R T-P C R)$. Total RNA from treated and control cells was prepared using the guanidium isothiocyanate-phenolchloroform method (24) and submitted to electrophoresis on $1 \%$ agarose gel containing ethidium bromide to verify the absence of genomic DNA contamination. Two micrograms of RNA were reverse transcribed for $2 \mathrm{~h}$ at $37^{\circ} \mathrm{C}$ in a $20 \mu 1$ reaction mixture containing $1 \mathrm{X}$ first-strand buffer, $0.5 \mathrm{mM}$ of each dNTP, $20 \mathrm{ng}$ random hexamer primers, $1.5 \mathrm{mM}$ $\mathrm{MgCl}_{2}, 2 \mathrm{U}$ RNase OUT and $10 \mathrm{U}$ Moloney murine leukaemia virus reverse transcriptase. A negative PCR control was performed without reverse transcriptase. The primers used for amplification were selected from published nucleotide sequences in the open reading frames of the human genes encoding Sema6B isoforms (25), GAPDH (26) and liver carnitine palmitoyltransferase 1 (CPT1 $\alpha$ ) (27) (Table I). GAPDH and CPT1 $\alpha$ were used as internal standard and positive control (28), respectively. Each primer was added at a final concentration of $0.2 \mu \mathrm{M}$ in a $50 \mu \mathrm{l}$ reaction mixture, containing $200 \mathrm{ng}$ cDNA, $0.2 \mathrm{mM}$ of each dNTP, $1.5 \mathrm{mM}$ $\mathrm{MgCl}_{2}, 1 \mathrm{X}$ PCR reaction buffer and $2.5 \mathrm{U}$ Taq polymerase. An initial denaturation step was carried out for $3 \mathrm{~min}$ at $94^{\circ} \mathrm{C}$. The following PCR program was performed in an automated thermal cycler (Bio-Rad): denaturation at $94^{\circ} \mathrm{C}$ for $40 \mathrm{sec}$, annealing for $40 \mathrm{sec}$ at $54^{\circ} \mathrm{C}$, then elongation at $72^{\circ} \mathrm{C}$ for $40 \mathrm{sec}$. This program was completed with a final extension of $10 \mathrm{~min}$ at $72^{\circ} \mathrm{C}$. Amplified DNA fragments were separated on $2 \%$ agarose gel and visualized by UV transillumination after ethidium bromide staining. Fluorescence intensity was quantified using a Gel Doc 2000 system (Bio-Rad). The PCR product amounts for Sema6B and GAPDH were all within the linear phase of the reaction using 28 PCR cycles for Sema6B, 18 cycles for GAPDH and 25 cycles for CPT $1 \alpha$ under these experimental conditions.

Real-time RT-PCR. Real-time PCR analyses were performed in a fluorescent iQ Cycler (Bio-Rad, Marnes-la-Coquette, France) with specific primers (Table I) yielding short PCR products suitable for SYBR Green detection. Samples in duplicate were processed in 96-well plates with the following conditions. Amplification reactions contained cDNA equivalent to $100 \mathrm{ng}$ RNA, $300 \mathrm{nM}$ of the sense and antisense primers in a volume of $20 \mu 1 \mathrm{using}$ the iQ SYBR Green supermix (BioRad). The thermal cycling conditions used were $95^{\circ} \mathrm{C}$ for $3 \mathrm{~min}$ to activate Taq polymerase, followed by 50 cycles of $10 \mathrm{sec}$ $94^{\circ} \mathrm{C}, 60^{\circ} \mathrm{C}, 72^{\circ} \mathrm{C}$ and $95^{\circ} \mathrm{C}$ for $5 \mathrm{sec}$. At the end of each run, melting-curve profiles were produced (cooling the samples to $70^{\circ} \mathrm{C}$ and heating to $90^{\circ} \mathrm{C}$ at a ramp rate of $0.1^{\circ} \mathrm{C} / 3 \mathrm{~s}$ with continuous measurement of fluorescence) to confirm amplification of specific transcripts.

Production and characterization of anti-semaphorin $6 B$ antibodies. The polyclonal anti-semaphorin 6B antibodies were raised against the amino-acid sequence, NH2FLEEFETYRPDRC-COOH, present in the extracellular part of the human transmembrane semaphorin 6B (25). The peptide sequence is conserved in rats (29) and humans but is specific to semaphorin 6B among semaphorins as determined from an analysis of sequences present in GenBank. The crosslinking of the synthesized peptide to keyhole limpet hemocyanin used as a carrier and the production of polyclonal antibodies by subcutaneous injection into rabbits were carried out by Sigma Chemical Corp.

A chimeric protein containing the full length sequence of rat Sema6B (formerly $R$-SemaZ) C-terminally tagged with a c-my sequence was produced by in vitro transcription and translation. The latter were performed using a rat Sema6B-cmyc pcDNA1.1 plasmid (29), the TNT-coupled wheat germ extract system and L-[ $\left.{ }^{35} \mathrm{~S}\right]$-methionine. Translated products were either directly submitted to SDS-PAGE on $8 \%$ gel 
Table I. Sequences of primers used in RT-PCR analyses.

\begin{tabular}{|c|c|c|c|c|}
\hline Genes & Techniques & Sequences $\left(5^{\prime}-3^{\prime}\right)$ sense & Sequences $\left(5^{\prime}-3^{\prime}\right)$ antisense & Refs \\
\hline Sema6B & $\begin{array}{c}\text { Semi-quantitaive } \\
\text { RT-PCR }\end{array}$ & GGGATGCTCTTCACAGCTACT & AGGTAGTTAAACTCCATCGCAATC & (33) \\
\hline GAPDH & $\begin{array}{c}\text { Semi-quantitaive } \\
\text { RT-PCR }\end{array}$ & GGTGAAGGTCGGTGTCAACG & GGGATCGCGCTCCTGGAAGG & $(34)$ \\
\hline $\mathrm{CPT} 1 \alpha$ & $\begin{array}{c}\text { Semi-quantitaive } \\
\text { RT-PCR }\end{array}$ & TGCTTTACAGGCGCAAACTG & TGGAATCGTGGATCCCAAA & $(35)$ \\
\hline Sema6B & $\begin{array}{l}\text { Real-time } \\
\text { RT-PCR }\end{array}$ & TCGGAGACAACATCAGCGGTATG & AATGGCTAGGAAGTCGGTAACAGTAG & (33) \\
\hline GAPDH & $\begin{array}{l}\text { Real-time } \\
\text { RT-PCR }\end{array}$ & АСССАСТССТССАССТTTGAC & TCCACCACCCTGTTGCTGTAG & $(34)$ \\
\hline
\end{tabular}

followed by autoradiography or incubated with anti-Sema6B antibody (diluted 1:100) and the complexes were immunoprecipitated using protein A-Sepharose and then analyzed by SDS-PAGE and autoradiography.

The polyclonal antibodies produced were characterized by immunocytochemistry analysis performed as described by Plénat et al (30). Frozen sections $(5 \mu \mathrm{m})$ were incubated overnight at $4{ }^{\circ} \mathrm{C}$ with the rabbit anti-semaphorin $6 \mathrm{~B}$ antibodies (diluted 1:1600). They were successively washed with $0.1 \mathrm{M}$ potassium phosphate buffer containing $0.1 \%$ (v/v) Tween-20, incubated with goat anti-rabbit biotinylated $\mathrm{IgG}$ solution (diluted 1:200) for $1 \mathrm{~h}$ at room temperature, and washed again. Sections were incubated with $6 \% \mathrm{H}_{2} \mathrm{O}_{2}$ for $15 \mathrm{~min}$ at room temperature and, after several washes, an incubation with streptavidin/peroxidase mix (diluted 1:200) was carried out for $1 \mathrm{~h}$ at room temperature. Sections were washed and peroxidase substrate (Vector NovaRed) was added for 5 min. Enzymic reaction was stopped by immersing the slides in bidistilled water. Negative controls were achieved with preimmune serum.

The characterization of the antibodies was also performed by immunoblotting with membrane-enriched fractions from MCF-7 cells. The latter were collected in TES buffer $(20 \mathrm{mM}$ Tris-base, pH 7.4, 1mM EDTA, pH 8.0, 150 mM NaCl, 0.25 M sucrose and a cocktail of protease inhibitors) and homogenized on ice with 30-40 cycles in Dounce homogenizer. The homogenate was centrifuged for $10 \mathrm{~min}$ at $500 \mathrm{x} \mathrm{g}$ at $4^{\circ} \mathrm{C}$. The resulting supernatant (crude cell extract) was spinned for $90 \mathrm{~min}$ at $100000 \mathrm{x} \mathrm{g}$ at $4^{\circ} \mathrm{C}$. The supernatant following this spin represents the $\mathrm{S} 100$ cytoplasmic fraction. The membraneenriched pellet after the foregoing centrifugation was solubilized for $1 \mathrm{~h}$ in solubilization buffer (10 mM Tris-base, pH 8.0, 1 mM EDTA, $100 \mathrm{mM} \mathrm{NaCl}, 1 \mathrm{mM}$ DTT and $0.1 \%$ NP-40) and centrifuged at $13000 \mathrm{x}$ for $3 \mathrm{~min}$ at $4^{\circ} \mathrm{C}$ to remove debris. Proteins from crude cell extracts, S100 and membrane fractions were submitted to Western blotting.

Western blot analysis. Concentrations of proteins from crude cell extracts, S100 or membrane fractions were determined (31). Protein samples were fractionated on $8 \%$ SDS-PAGE, transferred onto membrane filters. Immunoreactivity was detected using the produced anti-Sema6B antibody (diluted

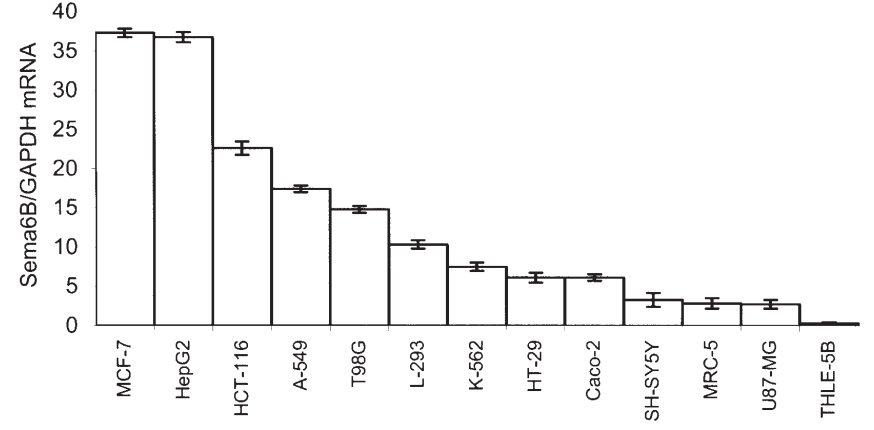

Figure 1. Sema6B mRNA expression in different human cell lines. Total RNA was extracted from cells after 5 days of culture and submitted to semiquantitative RT-PCR using specific primers for Sema6B and GAPDH genes. The ratios between the intensities of the Sema6B and GAPDH (used as internal standard) signals were determined. The bar graphs represent the mean $\pm \mathrm{SD}$ from 3 independent experiments.

1:500). GAPDH was used as an internal standard and detected by a specific antibody (diluted: 1/5000). Enhanced chemiluminescence was carried out according to the manufacturer's protocol.

Statistical analysis. Densitometric analyses of RT-PCR and Western blotting assays were carried out using a Gel Doc 2000 system. The data represent the mean \pm SD of three independent experiments. The statistical significance of differences between data from RT-PCR and Western blotting analyses were assessed by Student's-t-test. The acceptable level of significance was $\mathrm{P}<0.05$.

\section{Results}

Semaphorin 6B gene expression in different human cell lines. Thirteen well-characterized human cell lines were examined for Sema6B expression. Three independent cell cultures were carried out for total RNA extraction and semi-quantitative RT-PCR analysis with the specific primers for Sema6B. The relative Sema6B mRNA level was measured and compared to that of GAPDH used as an internal control. The human cell lines exhibited very different levels of Sema6B mRNA (Fig. 1). 


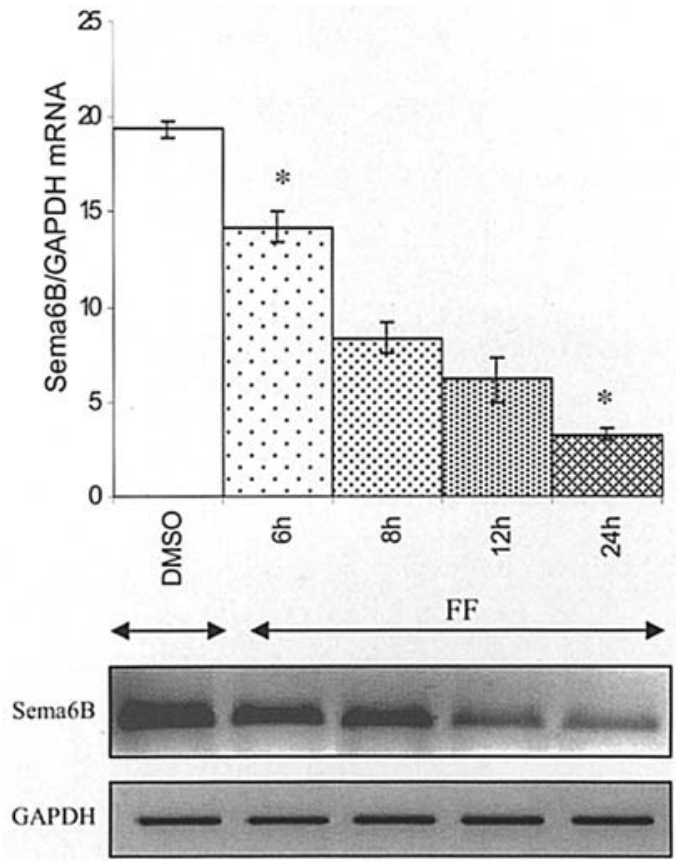

Figure 2. Effect of fenofibrate on Sema6B mRNA content in MCF-7 cells. Total RNA was extracted from cells exposed to $500 \mu \mathrm{M}$ fenofibrate for 6-24 h and subjected to RT-PCR analysis. For Sema6B (top), a pair of primers gave an expected 200-bp fragment. Data are normalized against the 138-bp GAPDH fragment (bottom). The bar graphs represent the mean \pm SD from 3 independent experiments. ${ }^{*} \mathrm{P}<0.05 ;{ }^{* *} \mathrm{P}<0.01$ versus control; $\mathrm{C}$, control; FF, fenofibrate.

The highest levels were expressed by MCF-7 breast adenocarcinoma cells and HepG2 hepatoblastoma cells. The Sema6B gene displayed average expression in HCT-116 colorectal carcinoma cells, A-549 lung cells and T98G glioblastoma cells. The lowest levels of Sema6B mRNA were found in L-293 kidney cells, chronic myelogenous leukemic K-562 cells, HT-29 and Caco-2 colorectal adenocarcinoma cells, SH-SY5Y neuroblastoma cells, MRC-5 lung cells, U-87 MG glioblastoma cells and THLE-5B liver cells. On the basis of these data, the MCF-7 cell line was selected for the following studies as it expresses the Sema6B gene at a high level, exhibits in vitro invasive capacity, and is frequently used as a model in studies dealing with semaphorins $(32,33)$.

Effects of PPAR activators on Sema6B mRNA level. The effects of $500 \mu \mathrm{M}$ fenofibrate, $10 \mu \mathrm{M}$ troglitazone and $1 \mu \mathrm{M}$ GW610742 on the Sema6B mRNA level were determined in MCF-7 cells by semi-quantitative RT-PCR. As shown in Fig. 2, a significant decrease in the Sema6B mRNA content of MCF-7 cells occurred within $6 \mathrm{~h}$ of fenofibrate treatment. A 4-fold decrease was noted after 24-h treatment. On the other hand, the CPT1 $\alpha$ mRNA level was increased in fenofibratetreated MCF-7 cells (Fig. 3), indicating that the fenofibrate treatment was efficient. A significant decrease was observed in Sema6B mRNA level when MCF-7 cells were treated with troglitazone for $24 \mathrm{~h}$ (Fig. 4). No significant change was noted in Sema6 mRNA content when cells were cultured with GW610742 for $24 \mathrm{~h}$ (data not shown).

Combined actions of PPAR and RXR agonists on Sema6B $m R N A$ level. As PPARs heterodimerize with RXRs before
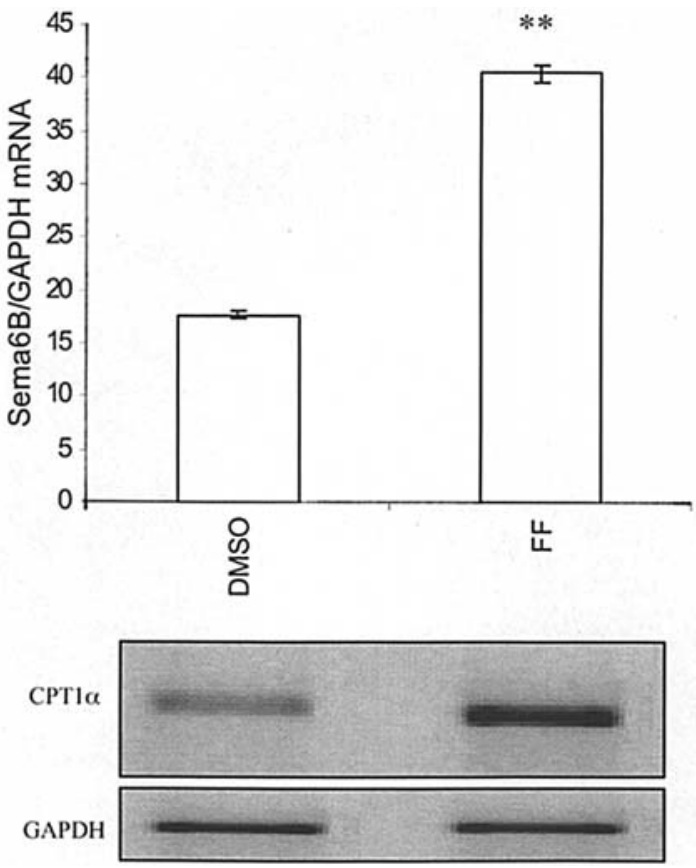

Figure 3. Effect of fenofibrate on the CPT1 $\alpha$ mRNA content in MCF-7 cells. Total RNA from cells exposed to $500 \mu \mathrm{M}$ fenofibrate for $24 \mathrm{~h}$ was extracted and subjected to RT-PCR analysis. For CPT1 $\alpha$ (top), a pair of primers gave an expected 625-bp fragment. Data are normalized against GAPDH (bottom). The bar graphs represent the mean \pm SD of 3 independent experiments. ${ }^{* *} \mathrm{P}<0.01$ versus control; $\mathrm{FF}$, fenofibrate.

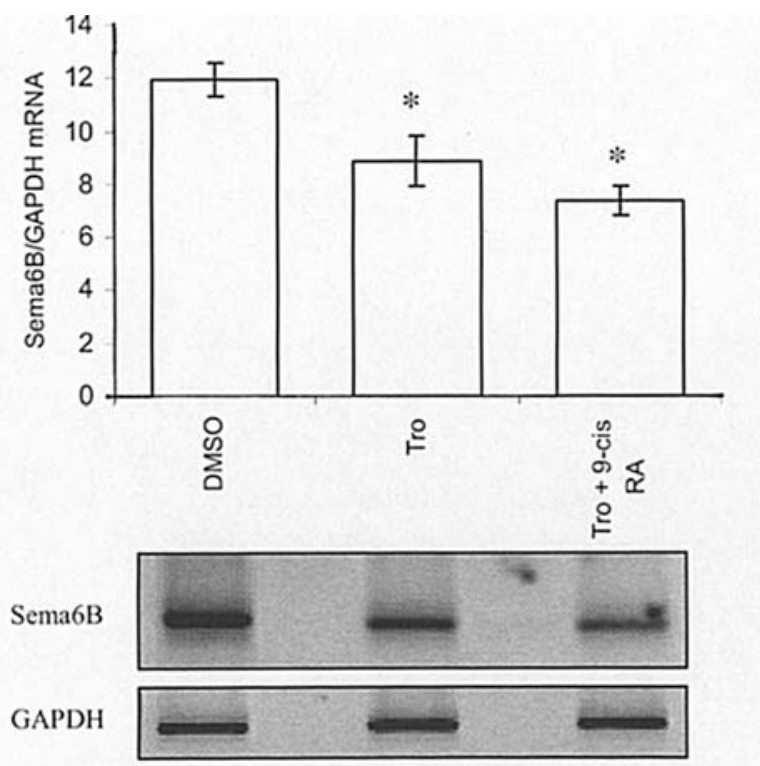

Figure 4. Effects of PPAR $\gamma$ and RXR activators on Sema6B mRNA level in $\mathrm{MCF}-7$ cells. The latter were treated for $24 \mathrm{~h}$ with $10 \mu \mathrm{M}$ troglitazone alone or with $1 \mu \mathrm{M} 9$-cis-retinoic acid. RT-PCR analyses were carried out for Sema6B and GAPDH. The ratios between the intensities of the Sema6B and GAPDH signals were determined. The bar graphs represent the mean $\pm \mathrm{SD}$ of 3 independent experiments. ${ }^{*} \mathrm{P}<0.05$ versus control; Tro, troglitazone; 9-cis-RA, 9-cis-retinoic acid.

binding to response elements of target genes, we investigated by semi-quantitative RT-PCR the combined effects of their activators on the Sema6B mRNA level of MCF-7 cells treated for $24 \mathrm{~h}$. No significant change was noted in the mRNA level 


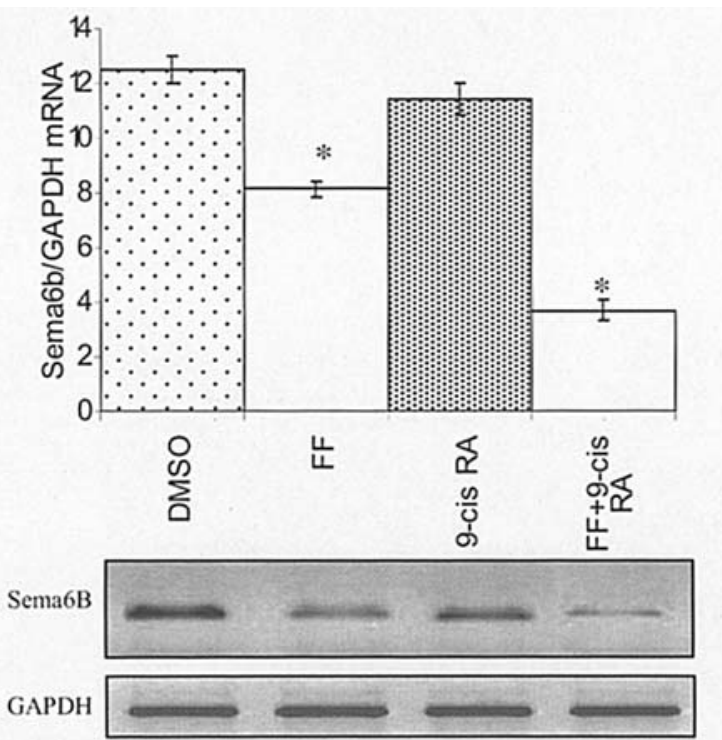

Figure 5. Effects of PPAR $\alpha$ and RXR activators on Sema6B mRNA level in MCF-7 cells. The latter were treated for $24 \mathrm{~h}$ with $500 \mu \mathrm{M}$ fenofibrate or $1 \mu \mathrm{M}$ 9-cis-retinoic acid, alone or in combination. RT-PCR analyses were carried out for Sema6B and GAPDH. The ratios between the intensities of the Sema6B and GAPDH signals were determined. The bar graphs represent the mean \pm SD of 3 independent experiments. ${ }^{*} \mathrm{P}<0.05$ and ${ }^{* *} \mathrm{P}<0.01$ versus control; FF, fenofibrate; 9-cis-RA, 9-cis-retinoic acid.

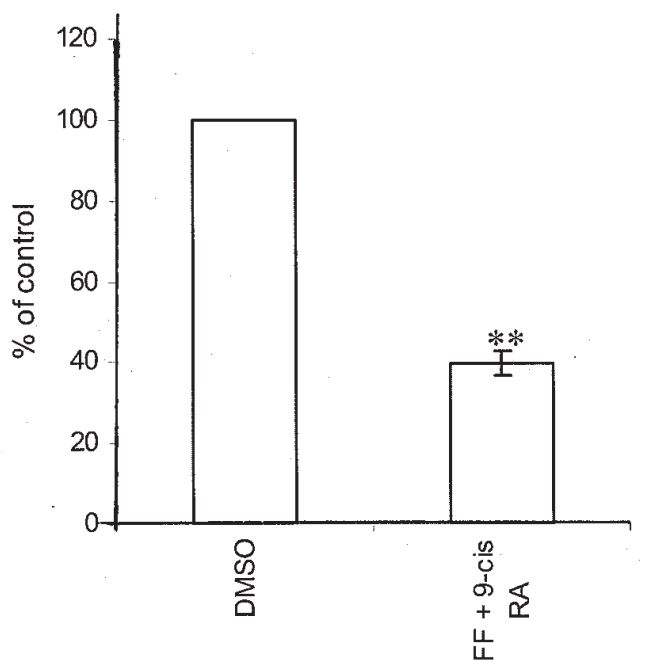

Figure 6. Sema6B mRNA quantification by real-time RT-PCR in MCF-7 cells co-treated for $24 \mathrm{~h}$ with $500 \mu \mathrm{M}$ fenofibrate and $1 \mu \mathrm{M}$ 9-cis-retinoic acid. The relative abundance of Sema6B transcripts in total RNA from control and treated cells was normalized relatively to GAPDH. Results from 3 independent experiments are expressed as mean percentages over untreated cells taken as $100 \% \pm \mathrm{SD} .{ }^{* * *} \mathrm{P}<0.01$ versus control; FF, fenofibrate; 9-cisRA, 9-cis-retinoic acid.

when the cells were treated with $1 \mu \mathrm{M}$ 9-cis-retinoic acid alone (Fig. 5). On the other hand, as expected, a marked decrease of Sema6B mRNA expression was observed upon treatment with $500 \mu \mathrm{M}$ fenofibrate alone. The decrease was more important when MCF-7 cells were simultaneously treated with fenofibrate and 9-cis-retinoic acid (Fig. 5). The latter data were confirmed by real-time RT-PCR analyses (Fig.6). The combined action for $24 \mathrm{~h}$ of troglitazone and 9-cis-retinoic acid decreased the Sema6B mRNA level (Fig. 4) whilst that

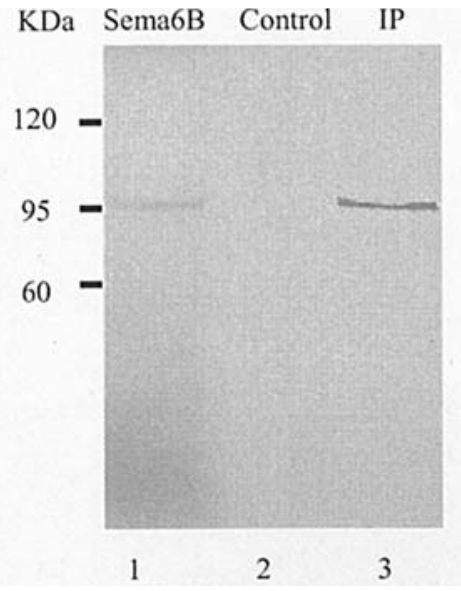

Figure 7. Recognition of in vitro-translated rat Sema6B by the antibody. Lanes 1, analysis by SDS-PAGE and autoradiography of the radioactive translated product (Sema6B); 2, negative control with an empty plasmid; 3 , immunoprecipitation (IP) assay of in vitro-translated rat Sema6B with the antibody. Molecular mass in kilodaltons is indicated on the left.
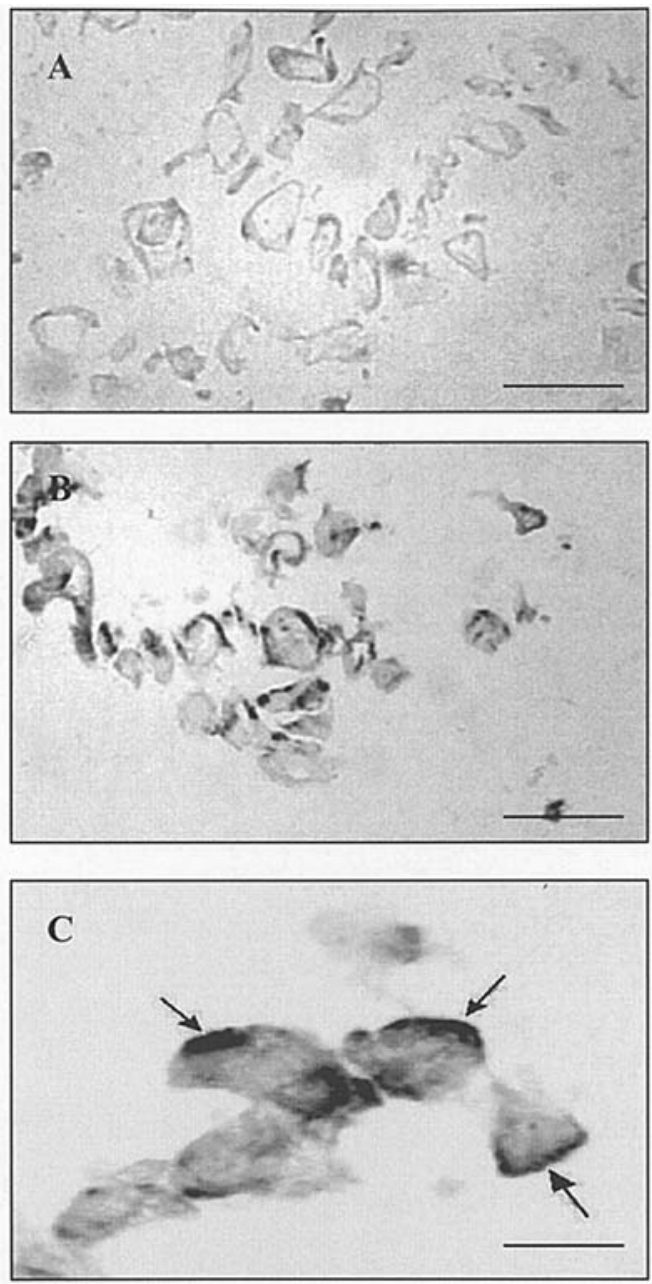

Figure 8 . Characterization of the anti-Sema6B antibody by immunocytochemistry. Expression of Sema6B in MCF-7 cells was analyzed using the produced polyclonal antibody (B-C). A control was carried out with preimmune serum (A). Arrows indicate membrane labeling. Bars, $50 \mu \mathrm{m}$; except $\mathrm{C}, 125 \mu \mathrm{m}$.

of GW610742 and 9-cis-retinoic acid did not induce any significant changes (data not shown). 


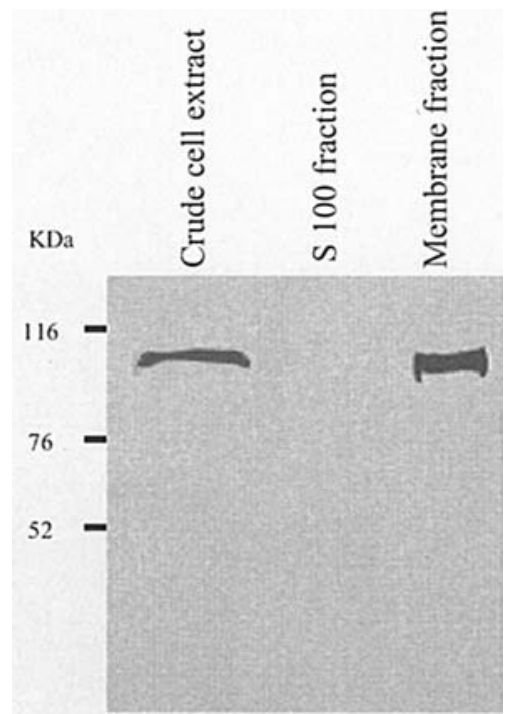

Figure 9. Characterization of the anti-Sema6B antibody by immunoblotting. Crude cell extracts, S100 and membrane fractions were prepared as described in Materials and methods. Proteins were fractionated by SDS-PAGE and probed with the anti-Sema6B antibody. Molecular mass in kilodaltons is indicated on the left.

Antibody specificity. Until now, the expression of the Sema6B protein has not been studied. As a first step in the expression analyses of this protein we produced a polyclonal antibody raised against a peptide located in the extracellular domain of the human semaphorin $6 \mathrm{~B}$. We verified that the signals obtained were specific for the Sema6B protein and not a consequence of a cross-reaction.

In vitro-translated rat Sema6B was used for immunoprecipitation assays, taking advantage of the human peptide sequence chosen for immunization being conserved in the corresponding rat sequence. Fig. 7 shows that the antibody recognized a protein band (lane 3) exhibiting the same apparent molecular weight as that obtained for in vitro-translated rat Sema6B (lane 1).

In immunocytochemical assays, a reactivity was detected in most MCF-7 cells (Fig. 8B). Higher magnifications reveal a strong membrane staining as expected for a transmembrane protein (Fig. 8C). Using the preimmune serum as a control, no signal was obtained (Fig. 8A).

Immunoblotting with crude extracts of MCF-7 cells, showed a protein band with an apparent molecular weight of approximately $110 \mathrm{kDa}$ (Fig. 9). The latter is very close to the calculated value, $95 \mathrm{kDa}$. The difference is probably due to the fact that semaphorin $6 \mathrm{~B}$ is a glycosylated protein. In addition, the antibody detected protein in the membrane fraction and not in the supernatant fraction (cytosolic fraction) confirming the immunocytochemical data.

Combined actions of PPAR and RXR agonists on Sema6B protein content. MCF-7 cells were simultaneously treated with $1 \mu \mathrm{M}$ 9-cis-retinoic acid and $500 \mu \mathrm{M}$ fenofibrate or $10 \mu \mathrm{M}$ troglitazone or $1 \mu \mathrm{M}$ GW610742 for $72 \mathrm{~h}$. Our Western blot analyses revealed that the semaphorin $6 \mathrm{~B}$ protein content was substantially decreased in MCF-7 cells treated with 9-cisretinoic acid and fenofibrate (Fig. 10) or with 9-cis-retinoic acid and troglitazone (Fig. 11). On the other hand, the

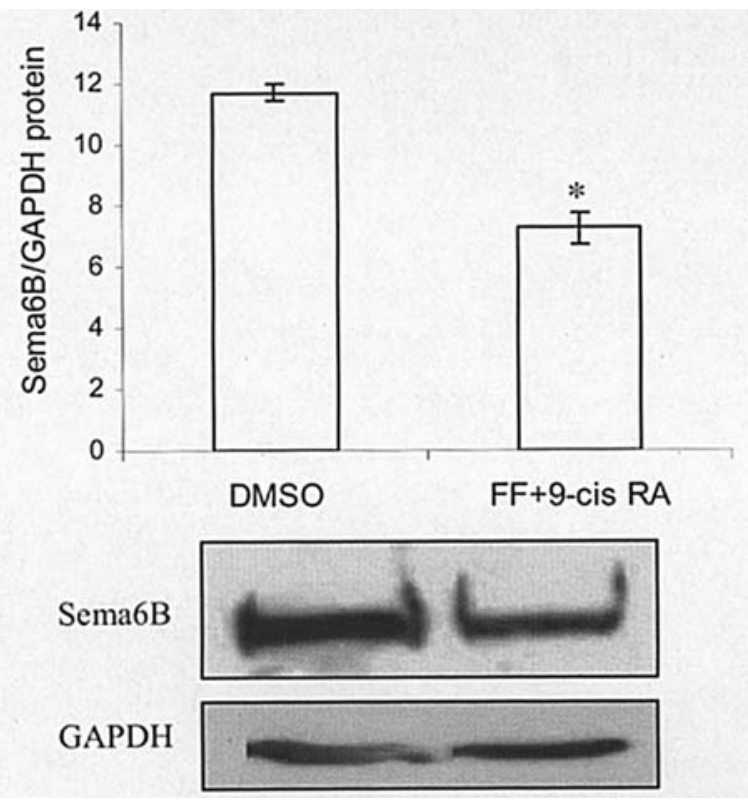

Figure 10. Combined action of PPAR $\alpha$ and RXR activators on the semaphorin $6 \mathrm{~B}$ protein content of MCF-7 cells. The latter were simultaneously treated with $500 \mu \mathrm{M}$ fenofibrate and $1 \mu \mathrm{M}$ 9-cis-retinoic acid for $72 \mathrm{~h}$. Protein extracts were submitted to Western blotting. Blots were first probed with the polyclonal antibody raised against the human semaphorin $6 \mathrm{~B}$, then with a polyclonal anti-GAPDH antibody. The intensities of the bands were quantified and the ratios between the intensities of the Sema6B and GAPDH signals were determined. The bar graphs represent the mean $\pm \mathrm{SD}$ of 3 independent experiments. ${ }^{*} \mathrm{P}<0.05$ versus control; FF, fenofibrate; 9-cis-RA, 9-cis-retinoic acid.

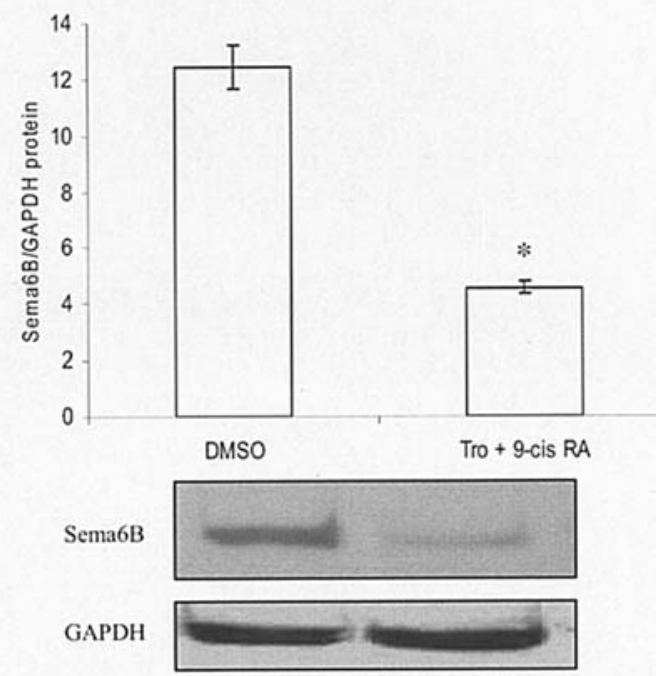

Figure 11. Combined action of PPAR $\gamma$ and RXR activators on the semaphorin 6B protein content of MCF-7 cells. The latter were simultaneously treated with $10 \mu \mathrm{M}$ troglitazone and $1 \mu \mathrm{M}$ 9-cis-retinoic acid for $72 \mathrm{~h}$. Protein extracts were submitted to Western blotting. Blots were first probed with the polyclonal antibody raised against the human semaphorin $6 \mathrm{~B}$, then with a polyclonal anti-GAPDH antibody. The intensities of the bands were quantified and the ratios between the intensities of the Sema6B and GAPDH signals were determined. The bar graphs represent the mean \pm SD of 3 independent experiments. ${ }^{*} \mathrm{P}<0.05$ versus control; Tro, troglitazone; 9-cis-RA, 9-cisretinoic acid.

semaphorin 6B protein content was not significantly changed by the simultaneous treatment of MCF-7 cells with 9-cisretinoic acid and GW610742 (data not shown). 


\section{Discussion}

The involvement of semaphorins in cancer is suggested by several reports (34). The class-3 semaphorins, in particular semaphorin $3 \mathrm{~B}$ and semaphorin $3 \mathrm{~F}$, function as potent inhibitors of tumor development in small cell lung carcinomas $(32,33,35,36)$. These semaphorins modulate the adhesive and migratory properties of responsive malignant cells and function as inhibitors of angiogenesis. Their anti-angiogenic properties contribute to their anti-tumorigenic properties (37-39). In contrast with these inhibitory semaphorins, there is now some evidence indicating that semaphorins, such as semaphorin $3 \mathrm{C}$ (40-42), semaphorin 3E (43), semaphorin 4D (44), semaphorin $5 \mathrm{~A}(45)$ and semaphorin $6 \mathrm{D}$ (6), may contribute to tumorigenesis or tumor progression.

To evaluate a possible role of Sema6B in the metastatic process, we analyzed its expression in different human cancer cell lines, some of which display in vitro invasive capacity. In a first step, semi-quantitative RT-PCR was used for a rough comparison of Sema6B gene expression levels. Despite the fact that the method used does not tell to what extent the gene is expressed in absolute terms, it does allow comparison of the levels of the Sema6B gene expression between the different cell lines examined. Our analysis showed that the highest levels of Sema6B mRNA levels were found in MCF-7 breast cells and HepG2 hepatoblastoma cells. The Sema6B mRNA levels noted in HCT 116 colorectal carcinoma cells, A-549 lung cells and T98-G glioblastoma cells were in an average range whereas the lowest levels were observed for the other cell lines examined.

Until now, the mechanisms involved in the regulation of the genes encoding the various semaphorins have not been investigated. We found that the Sema6B gene harbours a functional PPAR binding site in its promoter (9). Using a specific anti-Sema6B antibody that we have produced and characterized, the present study shows that fenofibrate induces a significant decrease in the semaphorin $6 \mathrm{~B}$ protein content of MCF-7 breast adenocarcinoma cells. It extends at the protein level, preliminary data obtained at the mRNA level for T98-G glioblastoma cells treated with other PPAR $\alpha$ activators (9). Moreover, it demonstrates that the repression exerted by PPAR $\alpha$ agonists is not limited to neural cells since Sema6B is also down-regulated in non-neural MCF-7 cells. In addition, it also reports for the first time that troglitazone, a PPAR $\gamma$ activator, is also able to down-regulate Sema6B gene expression in these cells. Because activated PPARs form heterodimers with RXR, we investigated the effects of 9-cis-retinoic acid, the ligand of RXR, alone or in combination with PPAR activators on the expression of the Sema6B gene in MCF-7 cells. A synergical effect was observed in the downregulation when cells were treated simultaneously with PPAR $\alpha$ or PPAR $\gamma$ and RXR ligands. On the other hand, no significant changes were observed in the Sema6B mRNA and protein levels when cells were treated with GW610742 and 9-cisretinoic acid. These data suggest that PPAR $\alpha / R X R$ and PPAR $\gamma /$ RXR heterodimers rather than PPARß/RXR heterodimers are involved in the down-regulation of the Sema6B gene expression.

Yet the function of class 6 semaphorins remains elusive. When the extracellular domain of Sema6A is expressed in mammalian cells as either a monomeric or a dimeric fusion protein and tested for potential axon guidance effects on populations of embryonic neurons in growth cone collapse and collagen matrix chemorepulsion assays, Sema6A was observed to induce growth cone collapse of sympathetic neurons (46). The membrane-bound semaphorins 6C and 6D also act as chemo-inhibitory molecules in neuronal development, a role similar to and probably overlapping that of the class-3 semaphorins (47). Like Sema6A, Sema6B was recently shown to inhibit the growth of sympathetic ganglion axons (48). Sema6B inhibitory activity is mediated by plexin-A4 to which recombinant Sema6B ectodomains can bind in vitro (48). It has also been shown that the cytoplasmic proline-rich domain of semaphorin 6B binds specifically the $\mathrm{SH} 3$ domain of the c-src protein suggesting that the semaphorin family not only serves as ligands but may include members, especially those which are transmembrane, which serve as receptors, triggering intracellular signalling via a src-related cascade (8). Outside the CNS, Sema6D-plexin-A1 reverse signalling controls in cardiac development, through a modulation of cell migration $(6,49)$. The semaphorins participating in cell recognition, adhesion/repulsion and migration are now emerging as critical molecules in tumor development.

In summary, these data show that the semaphorin $6 \mathrm{~B}$ gene is expressed at a high level in human MCF-7 cells that exhibit in vitro invasive capacity. Its level is down-regulated by fenofibrate or troglitazone and 9-cis-retinoic acid, the latter being an anti-proliferative, differentiation-promoting agent. As semaphorin 6B is now emerging as a key regulator of tumor progression, our data suggest that PPAR $\alpha / R X R$ and PPAR $\gamma / R X R$ heterodimers could play a role in this process by regulation of the Sema6B gene expression.

\section{Acknowledgements}

We are grateful to E. Brunner and A. Stoekel for their skillful technical assistance. H. Murad received a fellowship from the Atomic Energy Commission (Syria). This study was supported by grants from Association pour la Recherche contre le Cancer (ARC), la Ligue contre le Cancer (Comité de Meurthe et Moselle et Comité de Meuse), la Fondation pour la Recherche Médicale (Comité Lorraine), le Plan Etat-Région Lorraine and the Henri Poincaré-Nancy I University (BQR).

\section{References}

1. Kolodkin AL, Matthes DJ and Goodman CS: The semaphorin genes encode a family of transmembrane and secreted growth cone guidance. Cell 75: 1389-1399, 1993.

2. Luo Y, Raible D and Raper JA: Collapsin: a protein in the brain that induces the collapse and paralysis of neuronal growth cones. Cell 75: 217-227, 1993.

3. Tamagnone L and Comoglio PM: Signalling by semaphorin receptors: cell guidance and beyond. Biology 10: 377-383, 2000.

4. Goodman CS, Kolodkin AL, Luo Y, Pueschel AW and Raper JA: Unified nomenclature for the semaphorins collapsins. Cell 97: 551-552, 1999.

5. Raper JA: Semaphorins and their receptors in vertebrates and invertebrates. Curr Opin Neurobiol 10: 88-94, 2000.

6. Toyofuku T, Zhang, H, Kumanogoh A, Takegahara, N, Suto F, Kamei J, Aoki K, Yabuki M, Hori M, Fujisawa H and Kikutani H: Dual roles of Sema6D in cardiac morphogenesis through regionspecific association of its receptor, Plexin-A1, with off-tackand vascular endothelial growth factor receptor type 2 . Genes Dev 18: 435-447, 2004. 
7. Klostermann A, Lutz B, Gertler F and Behl C: The orthologous human and murine semaphorin 6A-1 proteins (SEMA6A-1/ Sema6A-1) bind to the enabled/vasodilator-stimulated phosphoprotein-like protein (EVL) via a novel carboxyl-terminal zyxinlike domain. J Biol Chem 275: 39647-39653, 2000.

8. Eckhardt F, Behar O, Calautti E, Yonezawa K, Nishimoto I and Fishman MC: A novel transmembrane semaphorin can bind c-src. Mol Cell Neurosci 9: 409-419, 1997.

9. Collet P, Domenjoud L, Devignes MD, Murad H, Schohn HA and Dauca M: The human semaphorin 6B gene is down-regulated by PPARs. Genomics 83: 1141-1150, 2004.

10. Escher P and Wahli W: Peroxisome proliferator-activated receptors: insight into multiple cellular functions. Mutat Res 448: 121-138, 2000.

11. Kliewer SA, Umesono K, Noonan DJ, Heyman RA and Evans RM: Convergence of 9-cis retinoic acid and peroxisome proliferator signalling pathways through heterodimer formation of their receptors. Nature 358: 771-774, 1992.

12. Stein GH: T98G: an anchorage-independent human tumor cell line that exhibits stationary phase G1 arrest in vitro. Cell 99: 43-54, 1979.

13. Beckman G, Beckman L, Ponten J and Westermark B: -6-PD and PGM phenotypes of 16 continuous human lines. Evidence against cross-contamination and contamination by HeLa cells. Hum Hered 21: 238-241, 1971.

14. Biedler JL, Roffler-Tarlov S, Schachner M and Freedman LS: Multiple neurotransmitter synthesis by human neuroblastoma cell lines and clones. Cancer Res 38: 3751-3757, 1978.

15. Knowles BB, Howe CC and Aden DP: Human hepatocellular carcinoma cell lines secrete the plasma proteins and hepatitis B surface antigen. Science 209: 497-499, 1980.

16. Pfeifer AM, Cole KE, Smoot DT, Weston A, Groopman JD, Shields PG, Vignaud JM, Juillerat M, Lipsky MM and Trump BF: Simian virus 40 large tumor antigen-immortalized normal human liver epithelial cells express hepatocyte characteristics and metabolize chemical carcinogens. Proc Natl Acad Sci USA 90: 5123-5127, 1993

17. Fogh J and Trempe G: Human Tumor Cells In Vitro. Fogh J (ed). pp115-141, 1975.

18. Brattain MG, Fine WD, Khaled FM, Thompson J and Brattain DE: Heterogeneity of malignant cells from a human colonic carcinoma. Cancer Res 41: 1751-1756, 1981.

19. Jacobs JP, Jones CM and Baille JP: Characteristics of a human diploid cell designated MRC-5. Nature 227: 168-170, 1970

20. Giard DJ, Aaronson SA, Todaro GJ, Arnstein P, Kersey JH, Dosik $\mathrm{H}$ and Park WP: In vitro cultivation of human tumors: establishment of cell lines derived from a series of solid tumors. J Natl Cancer Inst 51: 1417-1423, 1973.

21. Graham FL, Smiley J, Russell WC and Nairn R: Characteristics of a human cell line transformed by DNA from human adenovirus type 5. J Gen Virol 36: 59-74, 1977.

22. Brooks SC, Locke ER and Soule HD: Estrogen receptor in a human cell line (MCF-7) from breast carcinoma. J Biol Chem 248: 6251-6253, 1973.

23. Lozzio CB and Lozzio BB: Human chronic myelogenous leukemia cell-line with positive Philadelphia chromosome. Blood 45: 312-334, 1975.

24. Chomczynski P and Sacchi N: Single-step method of RNA isolation by acid guanidium thiocyanate-phenol-chloroform extraction. Anal Biochem 162: 156-159, 1987.

25. Correa RG, Sasahara RM, Bengtson MH, Katayama MLH, Salim ACM, Brentani MM, Sogayar MC, De Souza SJ and Simpson AJG: Human semaphorin 6B [(HSA)SEMA6B], a novel human class 6 semaphorin gene: alternative splicing and all-trans-retinoic acid-dependent down-regulation in glioblastoma cell lines. Genomics 73: 343-348, 2001.

26. Hanauer A and Mandel JL: The glyceraldehyde 3 phosphate dehydrogenase gene family: structure of a human cDNA and of an X chromosome linked pseudogene; amazing complexity of the gene family in mouse. EMBO J 3: 2627-2633, 1984.

27. Gobin S, Bonnefont JP, Prip-Buus C, Mugnier C, Ferrec M, Demaugre F, Saudubray JM, Rostane H, Djouadi F, Wilcox W, Cederbaum S, Haas R, Nyhan WL, Green A, Gray G, Girard J and Thuillier L: Organization of the human liver carnitine palmitoyltransferase 1 gene (CPT1A) and identification of novel mutations in hypoketotic hypoglycaemia. Human Genet 111: 179-189, 2002.

28. Louet JF, Le May C, Pegorier JP, Decaux JF and Girard J: Regulation of liver carnitine palmitoyltransferase I gene expression by hormones and fatty acids. Biochem Soc Trans 29: 310-316, 2001.
29. Kikuchi K, Ishida $\mathrm{H}$ and Kimura T: Molecular cloning of a novel member of semaphorin family genes, semaphorin $\mathrm{Z}$. Brain Res Mol Brain Res 51: 229-237, 1997.

30. Plénat F, Martinet Y, Martinet N and Vignaud JM: Immunohistochemical methods for studying mononuclear phagocytes in tissue sections. J Immunol Methods 174: 133-154, 1994.

31. Bradford MM: A rapid and sensitive method for the quantitation of microgram quantities of protein utilizing the principle of protein-dye binding. Anal Biochem 72: 248-254, 1976.

32. Roche J, Boldog F, Robinson M, Robinson L, Varella-Garcia M, Swanton M, Waggoner B, Fishel R, Franklin W, Gemmill R and Drabkin H: Distinct 3p21.3 deletions in lung cancer and identification of a new human semaphorin. Oncogene 12: 1289-1297, 1996.

33. Roche J and Drabkin HA: The role of semaphorins in lung cancer. Clin Lung Cancer 3: 145-150, 2001.

34. Neufeld G, Shraga-Heled N, Lange T, Guttmann-Raviv N, Herzog Y and Kessler O: Semaphorins in cancer. Front Biosci 10: 751-760, 2005.

35. Sekido Y, Bader S, Latif F, Chen JY, Duh FM, Wei MH, Albanesi JP, Lee CC, Lerman MI and Minna JD: Human semaphorin $\mathrm{A}(\mathrm{V})$ and IV reside in the $3 \mathrm{p} 21.3$ small cell lung cancer deletion region and demonstrate distinct expression patterns. Proc Natl Acad Sci USA 93: 4120-4125, 1996.

36. Nassare P, Constantin B, Rouhaud L, Harnois T, Raymond G, Drabkin HA, Bourmeyster N and Roche J: Semaphorin SEMA3F and VEGF have opposing effects on cell attachment and spreading. Neoplasia 5: 83-92, 2003.

37. Serini G, Valdembri D, Zanivan S, Morterra G, Burkhardt C, Caccavari F, Zammataro L, Primo L, Tamagnone L, Logan M, Tessier-Lavigne M, Taniguchi M, Puschel AW and Bussolino F: Class 3 semaphorins control vascular morphogenesis by inhibiting integrin function. Nature 424: 391-397, 2003.

38. Bates D, Taylor GI, Minichiello J, Farlie P, Cichowitz A, Watson N, Klagsbrun M, Mamluk R and Newgreen DF: Neurovascular congruence results from a shared patterning mechanism that utilizes Semaphorin3A and Neuropilin-1. Dev Biol 225: 77-98, 2003

39. Kessler O, Shraga-Heled N, Lange T, Gutmann-Raviv N, Sabo E, Baruch L, Machluf M and Neufeld G: Semaphorin-3F is an inhibitor of tumor angiogenesis. Cancer Res 64: 1008-1015, 2004

40. Yamada T, Endo R, Gotoh M and Hirohashi S: Identification of semaphorin $\mathrm{E}$ as a non-MDR drug resistance gene of human cancers. Proc Natl Acad Sci USA 94: 14713-14718, 1997.

41. Martin-Satue M and Blanco J: Identification of semaphorin E gene expression in metastatic human lung adenocarcinoma cells by mRNA differential display. J Surg Oncol 72: 18-23, 1999.

42. Rieger J, Wick W and Weller M: Human malignant glioma cells express semaphorins and their receptors, neuropilins and plexins. GLIA 42: 379-389, 2003

43. Christensen CR, Klingelhofer J, Tarabykina S, Hulgaard EF, Kramerov D and Lukanidin E: Transcription of a novel mouse semaphorin gene, M-semaH, correlates with the metastatic ability of mouse tumor cell lines. Cancer Res 58: 1238-1244, 1998.

44. Giordano S, Corso S, Conrotto P, Artigiani S, Gilestro G, Barberis D, Tamagnone L and Comoglio PM: The semaphorin $4 \mathrm{D}$ receptor controls invasive growth by coupling with Met Nat. Cell Biol 4: 720-724, 2002.

45. Artigiani S, Conrotto P, Fazzari P, Gilestro GF, Barberis D, Giordano S, Comoglio PM and Tamagnone L: Plexin-B3 is a functional receptor for semaphorin 5A. EMBO Rep 5: 710-714, 2004.

46. Xu XM, Fisher DA, Zhou L, White FA, Ng S, Snider WD and Luo Y: The transmembrane protein semaphorin 6A repels embryonic sympathetic axons. J Neurosci 20: 2638-2648, 2000 .

47. Qu X, Wei H, Zhai Y, Que H, Chen Q, Tang F, Wu Y, Xing G, Zhu Y, Liu S, Fan M and He F: Identification, characterization and functional study of the two novel human members of the semaphorin gene family. J Biol Chem 277: 35574-35585, 2002.

48. Suto F, Ito K, Uemara M, Shimizu M, Shinkawa Y, Sanbo M, Shinoda T, Tsuboi M, Takashima S, Yagi T and Fujisawa H: Plexin-a4 mediates axon-repulsive activities of both secreted and transmembrane semaphorins and plays roles in nerve fiber guidance. J Neurosci 6: 3628-3637, 2005.

49. Toyofuku T, Zhang H, Kumanogoh A, Takegahara N, Yabuki M, Harada K, Hori M and Kikutanu H: Guidance of myocardial patterning in cardiac development by Sema6D reverse signalling. Nat Cell Biol 6: 1204-1211, 2004. 